\title{
Climate Change Negotiations and Civil Society Participation: Shifting and Contested Terrain
}

\author{
Lauren Eastwood ${ }^{1}$
}

Based on ethnographic research in UN-based policy negotiations, I argue that civil society participation in global governance can best be thought through as it is played out in practice. Using examples from recent deliberations that have taken place under the auspices of the United Nations Framework Convention on Climate Change, I explore the politics of participation through a couple of key issues that are currently being worked out between UN member states and civil society organizations. While civil society serves an important role of providing technical expertise to UN deliberations, it can also serve to push the boundaries of which issues are taken up in negotiations. Tactics used by members of civil society, however, are not always consistent with UN business as usual. This article explores these dynamics and points to the implications of current tensions for future participation of civil society in climate-related negotiations. [Article copies available for a fee from The Transformative Studies Institute. E-mail address:_ journal@transformativestudies.org Website: http://www.transformativestudies.org (02011 by The Transformative Studies Institute. All rights reserved.]

KEYWORDS: Civil Society, Global Governance, Participation, Climate Change.

\footnotetext{
${ }^{1}$ Lauren Eastwood, Ph.D., is an Assistant Professor in the Department of Sociology and Criminal Justice at the State University of New York, Plattsburgh, where she teaches courses in Sociological Theory and Environmental Studies. She received her Ph.D. in Sociology in 2002 from Syracuse University. Her primary research investigates the participation of civil society in United Nations-based environmental policy making. She currently (2009-2011) holds a Social Science Research Council Abe Fellowship which supports her UN-related research. Address correspondence to: Lauren Eastwood, State University of New York-Plattsburgh, 101 Broad Street, Plattsburgh, NY 12903; e-mail: lauren.eastwood@plattsburgh.edu.

Acknowledgments: This research was assisted by a grant from the Abe Fellowship Program administered by the Social Science Research Council and the American Council of Learned Societies in cooperation with and with funds provided by the Japan Foundation Center for Global Partnership. I also appreciate the assistance of the Association of Third World Studies, Community Forests International, the Institute of Cultural AffairsGhana, and the Center for Earth and Environmental Science at the State University of New York at Plattsburgh, in providing documentation for meeting access.
} 